\title{
Microbiological quality and somatic cell count in bulk milk of dromedary camels (Camelus dromedarius): Descriptive statistics, correlations, and factors of variation
}

\author{
P. Nagy,${ }^{* 1}$ B. Faye,$\dagger$ O. Marko, ${ }^{*}$ S. Thomas, ${ }^{*}$ U. Wernery, $\ddagger$ and J. Juhasz* \\ ${ }^{*}$ Emirates Industries for Camel Milk and Products, Farm and Veterinary Section, Dubai, United Arab Emirates \\ †International Cooperation Center in Agronomic Research for Development (CIRAD), 34398 Montpellier Cedex, France \\ $\ddagger$ Central Veterinary Research Laboratory, Dubai, United Arab Emirates
}

\begin{abstract}
The objectives of the present study were to monitor the microbiological quality and somatic cell count (SCC) of bulk tank milk at the world's first large-scale camel dairy farm for a 2-yr period, to compare the results of 2 methods for the enumeration of SCC, to evaluate correlation among milk quality indicators, and to determine the effect of specific factors (year, season, stage of lactation, and level of production) on milk quality indicators. The study was conducted from January 2008 to January 2010. Total viable count (TVC), coliform count (CC), California Mastitis Test (CMT) score, and SCC were determined from daily bulk milk samples. Somatic cell count was measured by using a direct microscopic method and with an automatic cell counter. In addition, production parameters [total daily milk production (TDM, $\mathrm{kg}$ ), number of milking camels (NMC), average milk per camel (AMC, kg)] and stage of lactation (average postpartum days, PPD) were recorded for each test day. A strong correlation $(\mathrm{r}=0.33)$ was found between the 2 methods for SCC enumeration; however, values derived using the microscopic method were higher. The geometric means of SCC and TVC were $394 \times 10^{3}$ cells $/ \mathrm{mL}$ and $5,157 \mathrm{cfu} / \mathrm{mL}$ during the observation period, respectively. Somatic cell count was $>500 \times 10^{3}$ cells $/ \mathrm{mL}$ on $14.6 \%(106 / 725)$ and TVC was $>10 \times 10^{3} \mathrm{cfu} / \mathrm{mL}$ on $4.0 \%(30 / 742)$ of the test days. Both milk quality indicators had a distinct seasonal pattern. For log SCC, the mean was lowest in summer and highest in autumn. The seasonal pattern of log TVC was slightly different, with the lowest values being recorded during the spring. The monthly mean TVC pattern showed a clear difference between years. Coliform count was $<10 \mathrm{cfu} / \mathrm{mL}$ in most of the samples $(709 / 742,95.6 \%)$. A positive correlation was found
\end{abstract}

Received May 3, 2013.

Accepted May 17, 2013.

${ }^{1}$ Corresponding author: peter@camelicious.ae between $\log$ SCC and $\log$ TVC $(r=0.32)$, between log SCC and CMT score $(\mathrm{r}=0.26)$, and between log TVC and $\mathrm{CC}$ in yr $1(\mathrm{r}=0.30)$. All production parameters and stage of lactation showed strong seasonal variation. Log SCC was negatively correlated with TDM ( $\mathrm{r}=$ $-0.35)$, AMC $(\mathrm{r}=-0.37)$, and NMC $(\mathrm{r}=-0.15)$ and positively correlated with PPD $(r=0.40)$. Log TVC had a negative correlation with AMC $(\mathrm{r}=-0.40)$ but a positive correlation with NMC $(\mathrm{r}=0.32)$, TDM $(\mathrm{r}$ $=0.16)$, and PPD $(\mathrm{r}=0.45)$. The linear mixed model with stepwise variable selection showed that the main sources of $\log$ SCC variation were PPD, TDM, PPD $\times$ season, and season. For log TVC, the same factors and year contributed to the variation.

Key words: dromedary camel, bulk milk, somatic cell count, microbiological quality

\section{INTRODUCTION}

Following dairy cattle, water buffalo, goat, and sheep, camels are the fifth most important dairy animals in the world. This species provides approximately $0.3 \%$ of globally produced milk (1.7 million tonnes), but in some regions, such as the Horn of Africa, $10 \%$ of milk is derived from camels (Faye and Konuspayeva, 2012). However, most camel milk is produced in traditional farming or pastoral systems by hand milking that cannot provide consistent quantity and quality of raw milk for urban markets (Abeiderrahmane, 2005). The camel dairy industry, including machine milking, processing, and distribution, has been established in the last decade but it is still in an early stage of development (Nagy et al., 2013). Along with the development of the industry, regular and continuous monitoring of the quality of bulk camel milk has become necessary. Local and regional authorities and organizations have issued quality requirements (regulations and standards) specific for camel milk (GSO 1970/2009; GSO, 2009). However, these regulations are not supported by solid scientific data and require further improvement. 
As in milk of other species, the enumeration of total viable count (TVC) and coliform count (CC) have been used to describe the microbiological quality of raw camel milk (Teshager and Bayleyegn, 2001; Wernery et al., 2002; Khedid et al., 2003). However, reliable information on bulk milk quality is scarce. Reported values for TVC, mainly in samples from individual animals, range from few hundreds to millions of colony-forming units per milliliter (Wernery et al., 2002; Farah and Younan, 2005; Merin et al., 2005; Eberlein, 2007). In traditional management systems with hand milking and without proper temperature control, the TVC is generally $>10^{5} \mathrm{cfu} / \mathrm{mL}$ (Teshager and Bayleyegn, 2001; Farah and Younan, 2005; Merin et al., 2005). On the other hand, it is possible to produce high-quality raw camel milk (with TVC $<5 \times 10^{3} \mathrm{cfu} / \mathrm{mL}$ ) in both smalland large-scale farms by applying specific hygienic measures, milking routines, and milk cooling (Wernery et al., 2002; Eberlein, 2007; Nagy et al., 2013). Other quality parameters such as laboratory pasteurization count, psychrotrophic bacterial count, preliminary incubation count, and differentiated bacterial count have not yet been applied to monitor the quality of raw camel milk (Elmoslemany et al., 2009b; Pantoja et al., 2009; Bava et al., 2011).

In the bovine dairy industry, bulk tank SCC is a well-established and compulsory parameter to describe raw milk quality (Sargeant et al., 1998; Norman et al., 2011). Somatic cell counts have been determined in camel milk in the past but mainly from samples of individual animals to diagnose clinical or subclinical mastitis (Abdurahman et al., 1995; Abdurahman, 1996; Chaffer et al., 2000; Guliye et al., 2002; Saleh and Faye, 2011). In addition, most of the methods used were not validated and did not take into account the apocrine nature of milk secretion in this species. Like goat milk, camel milk contains a large proportion of anucleated cell fragments. The size of these cytoplasmic particles is similar to that of epithelial cells (Abdurahman et al., 1992; Paape et al., 2001). For this reason, the use of non-DNA-specific methods, such as particle counters or methylene blue staining, results in the over estimation of cell count in the milk (Petersson et al., 2011). For camel milk, counting procedures that are specific for DNA should be used to measure SCC. Recently, bulk milk samples from our farm were analyzed with a DNA-specific, automatic cell counter (Wernery et al., 2008). We also reported preliminary data on SCC values in bulk milk using direct microscopic counting after pyronin Y-methyl green (PMG) staining (Nagy et al., 2013). It is important to analyze a large number of bulk milk samples and to compare different methods to provide guidelines and reference values for SCC in camel milk.
The interaction between milk quality parameters and various factors influencing milk quality has been studied extensively in conventional dairy species. In cow and sheep milk, low bulk tank bacterial count is associated with low SCC and the increase in one parameter coincides with the increase of the other (Jayarao et al., 2004; Gonzalo et al., 2006a; Pantoja et al., 2009). Milk quality parameters are influenced by many factors, including year, season, month, herd, age, parity, breed, stage of lactation, intramammary infection, environmental factors, and management practices (Dulin et al., 1983; Paape et al., 2001; Jánosi and Baltay, 2004; Gonzalo et al., 2005, 2010; Elmoslemany et al., 2010; Dufour et al., 2011; Zucali et al., 2011). The complex interactions among the above-mentioned factors determine the final quality of the bulk tank milk. The role of these factors and their relationship with milk quality indicators have never been studied in camel milk.

The aims of the present study were to (1) monitor microbiological parameters and SCC for a 2-yr period in bulk camel milk at the world's first large-scale camel dairy farm; (2) compare the results of 2 methods for the enumeration of SCC; (3) define the interaction between milk quality indicators; and (4) evaluate the effect of some specific factors (year, season, stage of lactation, level of production) on these parameters.

\section{MATERIALS AND METHODS}

\section{Animals and Management of the Farm}

The study was conducted during a 2-yr period, from January 21, 2008, until January 21, 2010, at the premises of Emirates Industries for Camel Milk and Products (EICMP), the world's first large-scale camel dairy farm in Dubai, United Arab Emirates $\left(25^{\circ} \mathrm{N}, 55^{\circ}\right.$ E). The number of lactating camels ranged from 186 to 458 during this time. Animals were between 5 to $17 \mathrm{yr}$ of age, had variable parity, and belonged to different breeds. Dromedaries were kept in groups of 12 or 24 animals in open paddocks with sand bedding. Paddocks were cleaned twice a day. Calves were weaned partially and were kept in adjacent paddocks next to their dams throughout lactation. They were allowed to suckle after each milking. All camels had controlled exercise $(1 \mathrm{~h}$ walking) every day. The normal daily ration consisted of $4.2 \mathrm{~kg}$ of wheat bran, $2.4 \mathrm{~kg}$ of alfalfa pellet $(\sim 17 \%$ $\mathrm{CP}$ ) and $5 \mathrm{~kg}$ of locally produced hay (Rhodes hay) distributed in 4 portions throughout the day. Licking mineral stone and water were available ad libitum. Camels were in good body condition throughout lactation (BCS $\geq 3$ on the scale of 1 to 5 ). All dromedaries were identified both with a microchip and a visible running number placed on a collar on the neck. 


\section{Milking of Dromedaries: Milking Parlor and Milking Routine}

Dromedaries were milked twice a day with an automatic system in a $2 \times 12$ herringbone milking parlor. Milk yield $(\mathrm{kg})$ of individual dromedaries was measured during each milking with an International Committee for Animal Recording (ICAR)-approved milk meter. Data were collected by herd management software (Nagy et al., 2013). Before milking, the udder and teats were manually stimulated by gentle massage and were cleaned with a disposable, nonwoven tissue containing surfactant and quaternary ammonium compound (Profilac Dermapre, WestfaliaSurge, Bönen, Germany; MPS udder wipes, Anichem, Dubai, United Arab Emirates). The udder was also evaluated by the milker for the presence of clinical mastitis and injury. Camels with clinical mastitis or after prophylactic treatment were milked by hand and the milk was discarded. Postmilking teat dipping was not applied, and milkers wore gloves during milking. The milking system also included a plate cooler for rapid cooling of the milk. The milk was collected into a temperature-controlled bulk tank $(4,400$ L, RM/IB, Packo Invox, Zedelgem, Belgium) during both the morning and afternoon milking sessions. The temperature of the tank was recorded every $2 \mathrm{~h}$ and the milk was kept $<4^{\circ} \mathrm{C}$ at all times. Daily milk was transported to a nearby processing facility once a day after the evening milking. The washing of the parlor (cleaning-in-place) was carried out automatically twice a day after each milking alternating alkaline and acidic detergents. Before milking, the system was rinsed with warm water. The hot water temperature at the inlet was $>80^{\circ} \mathrm{C}$. Automatic washing of the tank was done once a day in the evening. Occasionally, the milk was collected after the morning milking followed by cleaning-in-place of the tank. Manual washing of the tank was performed once a week. The milking parlor was under a preventive maintenance contract including visits of competent technical staff every 4 to 6 mo.

\section{Sample Collection and Laboratory Analysis}

Bulk milk samples for bacteriology and SCC determination were collected in duplicate into sterile, $60-\mathrm{mL}$ sample containers at the end of the day (morning and afternoon milking combined). Before collection, the milk was stirred by the agitator of the tank for $5 \mathrm{~min}$ (Goodridge et al., 2004). Milk samples were taken to the laboratory immediately after collection and were kept at $4^{\circ} \mathrm{C}$ overnight until laboratory analysis.

Total viable count was determined on Milk Plate Count Agar (CM0681, Oxoid Ltd., Basingstoke, UK) using a plate-pouring technique with slight modifica- tion of the reference method (ISO 4833:2003; ISO, 2003). Samples were diluted at $10^{-1}, 10^{-2}$, and $10^{-3}$, and incubated at $37^{\circ} \mathrm{C}$ for $48 \mathrm{~h}$. Coliform count was determined on violet red bile agar (CM0107, Oxoid Ltd.) using the plate-pouring technique with dilutions at $10^{\circ}$ and $10^{-1}$. Samples were incubated at $30^{\circ} \mathrm{C}$ for $24 \mathrm{~h}$ (ISO 4832:2006; ISO, 2006).

Samples were subjected to the California Mastitis Test (CMT) on a scale from 0 to 3 (CMT-Test, Kruuse, Langeskov, Denmark). The enumeration of SCC was performed in 2 laboratories using different methods. In the laboratory of EICMP, a direct microscopic method (DMSCC) was used according to Paape at al. (2001) and Gonzalo at al. (2003) with some modifications. In brief, smears $(10 \mu \mathrm{L})$ in duplicate were prepared on somatic cell slides (5638-01930, Bellco Glass Inc., Vineland, NJ), air-dried overnight, and fixed in Carnoy's fixative for $10 \mathrm{~min}$. Then, slides were left again in air for 20 to $24 \mathrm{~h}$. Smears were stained by adding 2 drops of PMG (HT70116, Sigma-Aldrich, St. Louis, MO) for 2 min. Then, PMG stain was removed with absorbent paper without further washing. Somatic cells were counted on 20 fields of one smear using a light microscope at $200 \times$ magnification. For every 10 samples, cells were counted on both smears and the coefficient of variation was determined. Final values (cells $/ \mathrm{mL}$ ) were calculated using the following equation: SCC/ $\mathrm{mL}=(\Sigma 20$ fields $) \times 526.4$. One milk sample was sent to another laboratory (Central Veterinary Research Laboratory, CVRL, Dubai, United Arab Emirates), where SCC was measured in undiluted samples after 12 to $24 \mathrm{~h}$ of storage at $4^{\circ} \mathrm{C}$ with an automatic cell counter (DCC, DeLaval, Tumba, Sweden; Gonzalo et al., 2006b; Berry and Broughan, 2007; Wernery et al., 2008).

\section{Production Parameters}

For each production day, the following parameters were recorded: date (year: yr 1 from January 21, 2008, to January 20, 2009; yr 2 from January 21, 2009, to January 21, 2010); month; season (winter $=$ December to February, spring $=$ March to May, summer $=$ June to August, and autumn = September to November); total daily milk production (TDM, $\mathrm{kg}$ ); individual daily milk yield $(\mathrm{kg})$; number of milking camels (NMC); and stage of lactation (postpartum days) of each milked animal. From these data, additional parameters were calculated: average milk per camel (AMC, kg) and average postpartum days (PPD).

\section{Statistical Analysis}

As SCC and TVC values are typically log-normal (Shook, 1982), data analysis was performed with log 
data. Means and SD were calculated after logarithmic transformation of the raw data. However, the values were transformed back to the original scale, in cells per milliliter and colony-forming units per milliliter, resulting in geometric means. The test of Shapiro-Wilk was used for verifying the normality of the raw data.

Methods (DMSCC vs. DCC SCC) for the enumeration of SCC were compared first with Pearson correlation, and the effect of method on SCC values was assessed by ANOVA.

Relationships and variation factors were tested using different approaches. First, samples were categorized according to SCC, CC, and CMT scores. Based on SCC distribution, 4 categories of SCC were defined: low SCC $\left(<300 \times 10^{3}\right.$ cells $\left./ \mathrm{mL} ; \mathrm{n}=76\right)$, medium SCC $(300-400$ $\times 10^{3}$ cells $\left./ \mathrm{mL} ; \mathrm{n}=290\right)$, high $\mathrm{SCC}\left(400-500 \times 10^{3}\right.$ cells $/ \mathrm{mL} ; \mathrm{n}=253)$ and very high $\mathrm{SCC}\left(>500 \times 10^{3}\right.$ cells $/ \mathrm{mL} ; \mathrm{n}=106)$. Samples were also divided into 3 CC categories: nondetectable CC (ND, $\mathrm{n}=436)$, few $\mathrm{CC}(1-10 \mathrm{cfu} / \mathrm{mL} ; \mathrm{n}=272)$ and high $\mathrm{CC}(>10 \mathrm{cfu} / \mathrm{mL}$; $\mathrm{n}=34)$. Quantitative data (log TVC, production parameters, stage of lactation) and qualitative parameters (CMT and CC categories) were compared with ANOVA and $\chi^{2}$-test according to SCC categories, respectively. Difference in log SCC and in log TVC among CC categories and CMT scores was tested by ANOVA.

Effects of seasonal changes and the year differences on milk quality indicators were studied by ANOVA using month, season, and year as independent fixed factors. Seasonal differences in production parameters (TDM, AMC, NMC) and stage of lactation (PPD) were also tested by ANOVA. Group means were compared by the least significant different (LSD) post hoc test. The correlation between milk quality indicators, production parameters, and stage of lactation was evaluated by Pearson correlation.

Finally, a linear mixed model with stepwise variable selection was applied for $\log$ SCC and for $\log$ TVC separately. To assess autocorrelation, a correlogram was prepared (Shumway and Stoffer, 2001). The autocorrelogram showed the lack of autocorrelation after $4 \mathrm{~d}$ for both SCC and TVC. Therefore, the linear mixed model with stepwise variable selection tested the effect of quantitative and qualitative variables on weekly means of $\log$ SCC and $\log$ TVC. The quantitative explanatory variables were TDM and PPD. The qualitative explanatory variables were year, season, and $\mathrm{CC}$ category. Due to multicollinearity, AMC and NMC were discarded from the final model. All 2-way interactions were included in the model $(\mathrm{PPD} \times$ season, $\mathrm{PPD}$ $\times$ year, TDM $\times$ season, TDM $\times$ year $)$. For all statistical analysis, the XLStat software was used (Addinsoft, Anglesey, UK).

\section{RESULTS}

\section{Comparison of Methods (DMSCC vs. DCC SCC) for Somatic Cell Enumeration}

Weekly mean values are shown in Figure 1. We found a strong correlation between results by the 2 methods $(\mathrm{r}=0.33 ; P<0.001)$. However, $\mathrm{SCC}$ values by DMSCC were higher compared with those by DCC (geometric mean: $398 \times 10^{3}$ for DMSCC vs. $363 \times 10^{3}$ cells $/ \mathrm{mL}$ for DCC SCC; $P<0.001)$. In addition, a year difference was observed: the correlation was higher in yr $1(\mathrm{r}=$ $0.44)$ than in yr $2(r=0.23)$. Higher DMSCC values were observed mainly at the beginning of monitoring and then from wk 60 to 64 (March 2009) and from wk 71 to 73 (May 2009). The coefficient of variation was the same $(23.5 \%)$ for the 2 methods. For descriptive statistics and further analysis, values obtained with the reference method (DMSCC) were used.

\section{Descriptive Statistics and Seasonal Changes}

Mean SCC Values and Changes in SCC. During the observation period, the geometric mean of SCC was $394 \times 10^{3}$ cells $/ \mathrm{mL}$ with a range of 113,702 to 927,423 . The median $\left(398 \times 10^{3}\right.$ cells $\left./ \mathrm{mL}\right)$ was close to the mean, but the distribution was not normal $(P$ $<0.001$ ). Distribution of samples in different SCC categories (low, medium, high, and very high) is shown in Table 1 . Most values $(75 \%)$ ranged from 300 to $500 \times$ $10^{3}$ cells $/ \mathrm{mL}$. Low values $\left(<300 \times 10^{3}\right.$ cells $\left./ \mathrm{mL}\right)$ were observed in only $10.5 \%$ of the cases. The mean coefficient of variation of the duplicates was $3.5 \%$ with a range of 0.1 to $21.0 \%$. Daily variation in SCC is shown in Figure 2. Monthly means decreased significantly from April to August $(P<0.001)$, but the seasonal pattern was different between the years. The decrease in mean SCC during spring and summer was marked in yr 1 compared with yr 2 (Figure 3 ). The year effect was confirmed because the proportion of low SCC category was higher in yr 1, whereas that of the very high SCC category was increased in yr $2(P<0.001)$.

Mean TVC Values and Changes in TVC. Throughout the study, the geometric mean of TVC was $5,157 \mathrm{cfu} / \mathrm{mL}$, with a range of 2,018 to 63,400 . Geometric mean was higher in yr $2(6,270 \mathrm{cfu} / \mathrm{mL})$ compared with yr $1(4,220 \mathrm{cfu} / \mathrm{mL} ; P<0.001)$. The median was $5,086 \mathrm{cfu} / \mathrm{mL}$ and TVC was $<10 \times 10^{3}$ $\mathrm{cfu} / \mathrm{mL}$ on most of the test days $(712 / 742,96 \%)$. The daily change in TVC values was relatively close to that of SCC, especially when high values $\left(>10 \times 10^{3} \mathrm{cfu} /\right.$ $\mathrm{mL} ; 30$ samples, $4 \%$ ) were discarded from the time series (Figure 2). The seasonal variation of log TVC 


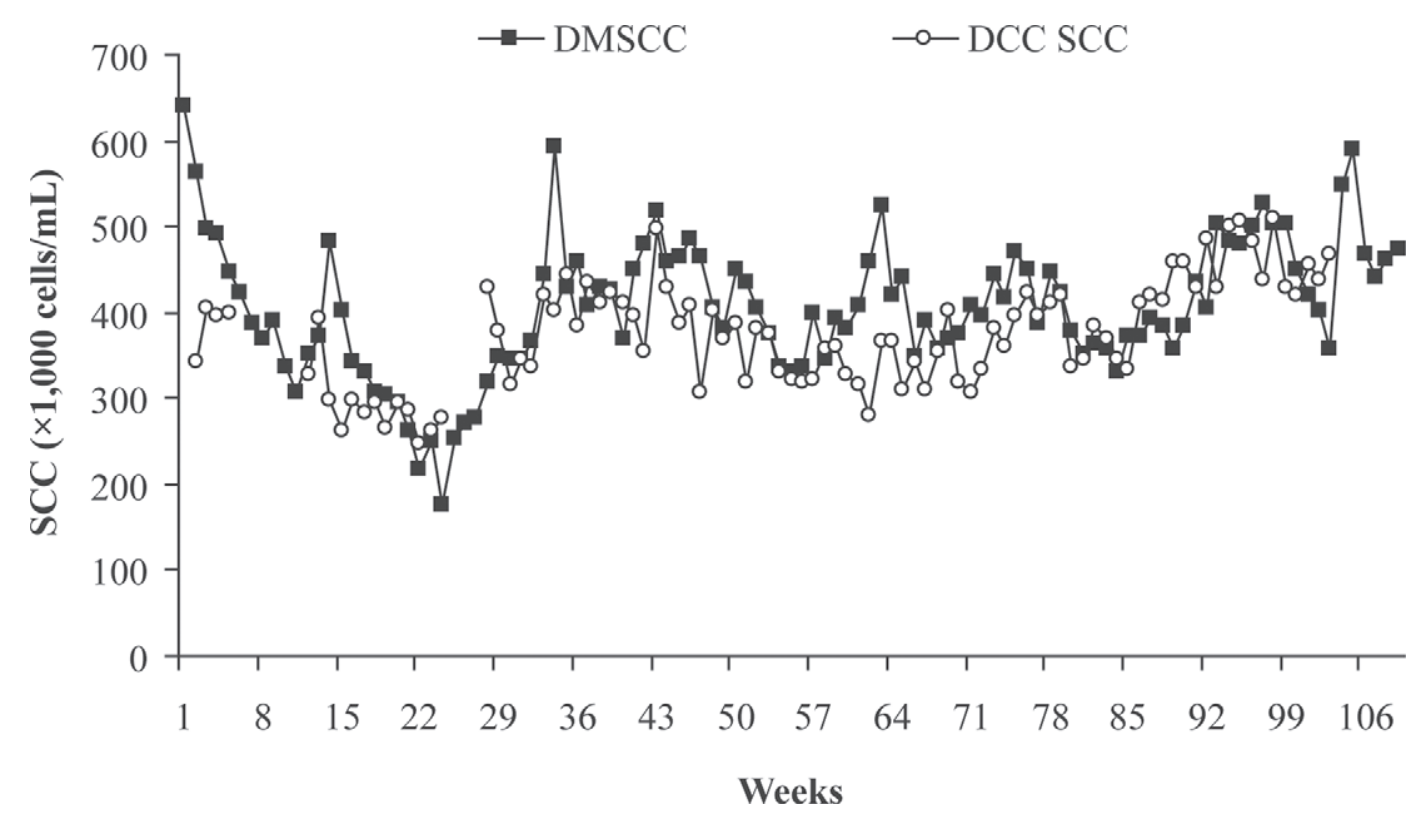

Figure 1. Changes in weekly mean SCC in bulk camel milk according to the method of somatic cell enumeration: direct microscopic method (DMSCC) versus automatic cell counter: DCC SCC (DeLaval, Tumba, Sweden).

showed higher values in winter and autumn compared with the spring $(P<0.001)$. Values reported in the summer were at an intermediate level but were different from those of the other seasons $(P<0.01)$. This seasonal pattern was slightly different from that of log SCC (Figure 4), as the lowest SCC values occurred in summer. The monthly mean TVC pattern showed a clear difference between the years (Figure 3). In 2008, monthly mean decreased in the spring and summer. In contrast, mean TVC increased from March to July in 2009. Most of the high TVC values $\left(>10 \times 10^{3} \mathrm{cfu} / \mathrm{mL}\right.$, $25 / 30,83 \%$ ) have been recorded during this period.
Mean CC Values and Changes in CC. The arithmetic mean $( \pm \mathrm{SD})$ of $\mathrm{CC}$ was $2.6 \pm 19.1 \mathrm{cfu} / \mathrm{mL}$ with a range of 0 to 390 . The $\mathrm{CC}$ was $<10 \mathrm{cfu} / \mathrm{mL}$ in most samples (709/742, 95.6\%). High values (>10 cfu/ $\mathrm{mL} ; 33 / 742,4.4 \%$ ) were concentrated in few months during the study. This resulted in peaks of monthly mean (September 2008 and August 2009) but no seasonal variation was observed (Figure 3 ).

\section{Correlation Between Milk Quality Indicators}

The correlation between daily $\log$ SCC and log TVC was significant $(\mathrm{r}=0.32 ; P<0.001)$ irrespective of

Table 1. Mean values of different parameters according to SCC categories ${ }^{1}$

\begin{tabular}{lcccc}
\hline & $\begin{array}{c}\text { Low SCC } \\
\text { Item }^{2}\end{array}$ & $\begin{array}{c}\text { Medium SCC } \\
\mathrm{n}=76(10.5 \%)\end{array}$ & $\begin{array}{c}\text { High SCC } \\
\mathrm{n}=290(40.0 \%)\end{array}$ & $\begin{array}{c}\text { Very high SCC } \\
\mathrm{n}=253(34.9 \%)\end{array}$ \\
\hline Quantitative data $=106(14.6 \%)$ \\
Mean SCC (cells/mL) & $250,665^{\mathrm{d}}$ & $354,047^{\mathrm{c}}$ & $442,242^{\mathrm{b}}$ & $562,021^{\mathrm{a}}$ \\
Mean TVC (cfu/mL) & $3,963^{\mathrm{c}}$ & $4,831^{\mathrm{b}}$ & $5,623^{\mathrm{a}}$ & $5,998^{\mathrm{a}}$ \\
TDM (kg) & $2,179^{\mathrm{a}}$ & $2,096^{\mathrm{b}}$ & $1,971^{\mathrm{c}}$ & $1,699^{\mathrm{c}}$ \\
AMC (kg) & $6.7^{\mathrm{a}}$ & $6.1^{\mathrm{b}}$ & $5.9^{\mathrm{c}}$ & $5.8^{\mathrm{c}}$ \\
NMC & $329^{\mathrm{a}}$ & $345^{\mathrm{a}}$ & $339^{\mathrm{a}}$ & $286^{\mathrm{b}}$ \\
PPD (d) & $289^{\mathrm{d}}$ & $322^{\mathrm{c}}$ & $340^{\mathrm{b}}$ & $349^{\mathrm{a}}$ \\
Qualitative data & & & & \\
CMT1 (\%) & $31.5^{\mathrm{a}}$ & $6.7^{\mathrm{b}}$ & $2.9^{\mathrm{c}}$ & $0.0^{\mathrm{c}}$ \\
CMT2 (\%) & $56.2^{\mathrm{a}}$ & $72.3^{\mathrm{b}}$ & $73.3^{\mathrm{b}}$ & $89.3^{\mathrm{c}}$ \\
CC absent (\%) & $68.4^{\mathrm{a}}$ & $58.9^{\mathrm{a}}$ & $54.1^{\mathrm{b}}$ & $622^{\mathrm{a}}$ \\
CC >10 cfu/mL (\%) & $2.6^{\mathrm{a}}$ & $5.2^{\mathrm{a}}$ & $5.1^{\mathrm{a}}$ & $1.9^{\mathrm{a}}$ \\
\hline
\end{tabular}

$\overline{\mathrm{a}-\mathrm{d}}$ Different superscripts within row indicate difference at $P<0.05$.

${ }^{1}$ Low $\mathrm{SCC}=<300 \times 10^{3}$ cells $/ \mathrm{mL}$; medium $\mathrm{SCC}=300$ to $400 \times 10^{3}$ cells $/ \mathrm{mL}$; high $\mathrm{SCC}=400$ to $500 \times 10^{3}$ cells $/ \mathrm{mL}$; very high $\mathrm{SCC}=>500 \times 10^{3}$ cells $/ \mathrm{mL}$.

${ }^{2} \mathrm{TVC}=$ total viable count; $\mathrm{TDM}=$ total daily milk $(\mathrm{kg}) ; \mathrm{AMC}=$ average milk per camel $(\mathrm{kg}) ; \mathrm{NMC}=$ number of milking camels; PPD = postpartum days; CMT = California Mastitis Test (score 1 or 2); CC = coliform count. 


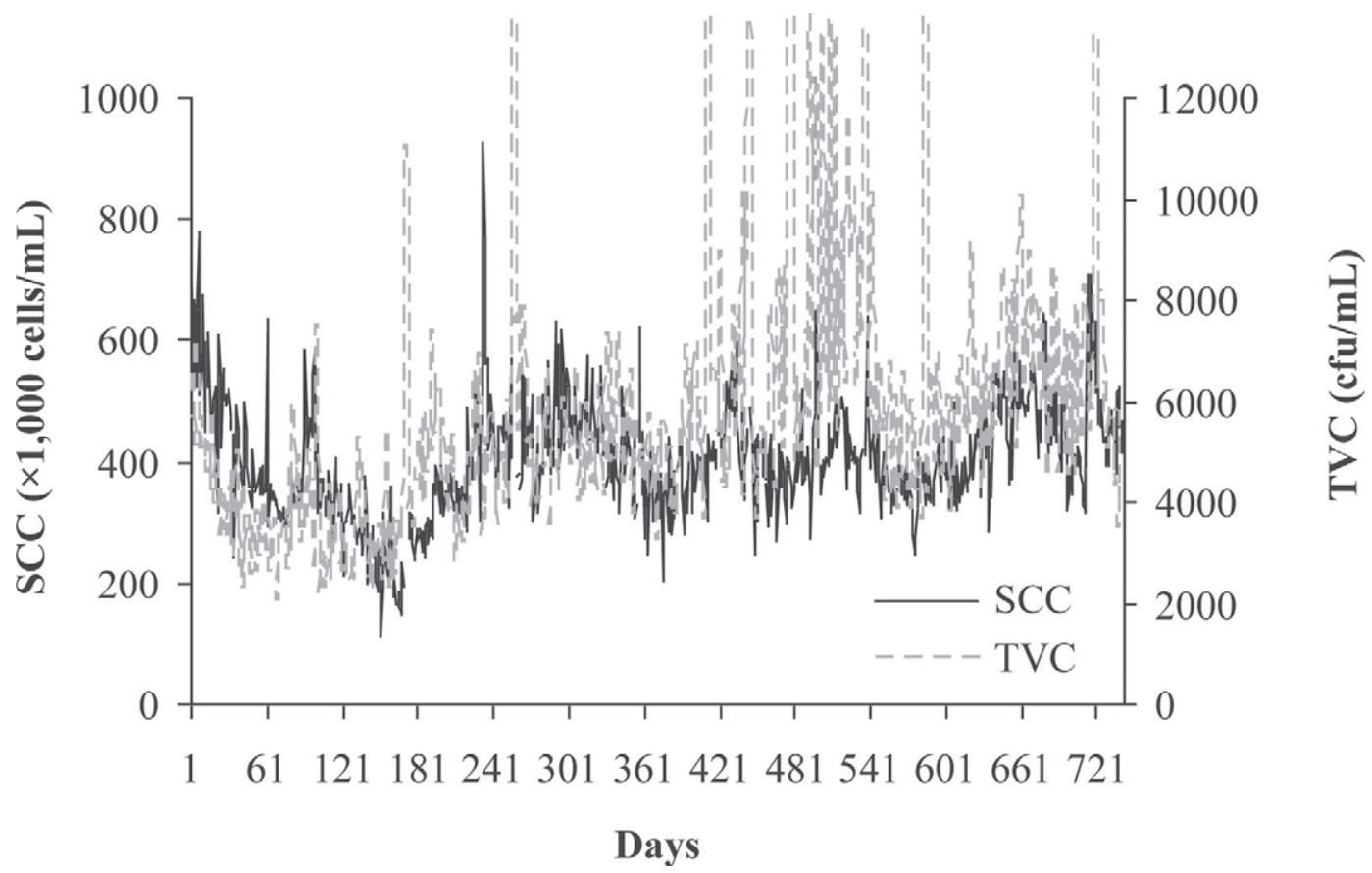

Figure 2. Daily changes in SCC and total viable count (TVC) in bulk camel milk throughout the study from January 21, 2008 (d 1), until January 21, 2010.

the year (Table 2, Figure 4). By discarding high TVC values $\left(>10 \times 10^{3} \mathrm{cfu} / \mathrm{mL}\right)$, the correlation coefficient increased slightly $(\mathrm{r}=0.33 ; P<0.001)$. The $\log$ TVC also differed according to SCC categories $(P<0.001)$. The geometric mean of TVC increased from low to high SCC categories (Table 1).

No correlation was found between $\log \mathrm{SCC}$ and $\mathrm{CC}$ $(\mathrm{r}=0.004$; Table 2) and mean log SCC did not differ between $\mathrm{CC}$ categories. In addition, the distribution of low or high CC categories did not show any difference or clear tendency among the SCC categories (Table 1).

We found a positive correlation between $\log$ SCC and CMT $(\mathrm{r}=0.26, P<0.001)$. A CMT score of 1 was more represented in low SCC category samples, whereas a CMT score of 2 was more frequent in medium, high and very high SCC samples (Table 1). The geometric mean of SCC increased with increasing CMT score: 297 $\times 10^{3}, 396 \times 10^{3}$, and $405 \times 10^{3}$ cells $/ \mathrm{mL}$ for CMT 1 $(\mathrm{n}=47)$, CMT $1.5(\mathrm{n}=132)$, and CMT 2 samples (n $=499$ ), respectively. However, the difference between CMT scores 1.5 and 2 was not significant.

We observed a weak positive correlation between log TVC and CC categories including all data $(\mathrm{r}=0.09, P$ $<0.05$ ). However, the relationship was different between years. In yr 1 , the correlation was highly positive $(\mathrm{r}=$ $0.30, P<0.001)$ and the geometric mean of $\log$ TVC increased from ND to high CC category $(P<0.001$, Figure 5). In contrast, the relationship was negative (r $=-0.11, P<0.05)$ during yr 2 . The geometric mean of
ND CC category was the highest, but ANOVA did not confirm difference in log TVC among CC categories.

\section{Changes in Production Parameters and Stage of Lactation, Correlation with Milk Quality Indicators, and Factors of Variation}

All production parameters (TDM, AMC, NMC) and stage of lactation (PPD) showed a strong seasonal variation. Mean $( \pm \mathrm{SD}) \mathrm{TDM}, \mathrm{AMC}$, and NMC were the highest during summer and lowest during winter (Table 3). Average total daily milk was $2,346 \mathrm{~kg}$ in the summer and $1,738 \mathrm{~kg}$ in the winter. In contrast, mean postpartum day was the highest in the autumn (335 d) and lowest during the spring (292 d; Table 3). In general, a close relationship was found among production parameters and stage of lactation (Table 2). Total daily milk production was closely related to NMC $(\mathrm{r}=0.87$, $P<0.001)$ and a negative correlation was observed between AMC and NMC $(\mathrm{r}=-0.44, P<0.001)$. Average postpartum days was significantly correlated to both $\operatorname{AMC}(\mathrm{r}=-0.55)$ and NMC $(\mathrm{r}=0.17)$.

Somatic cell count values decreased with increasing TDM, AMC, and NMC. The correlation of log SCC was negative $(P<0.001)$ with TDM $(\mathrm{r}=-0.35$, Figure $6)$, AMC $(\mathrm{r}=-0.37)$, and NMC $(\mathrm{r}=-0.15$; Table 2$)$. In contrast, the correlation between $\log \mathrm{SCC}$ and $\mathrm{PPD}$ was highly positive $(\mathrm{r}=0.40, P<0.001)$. Log SCC values increased with increasing PPD (Figure 7). These 

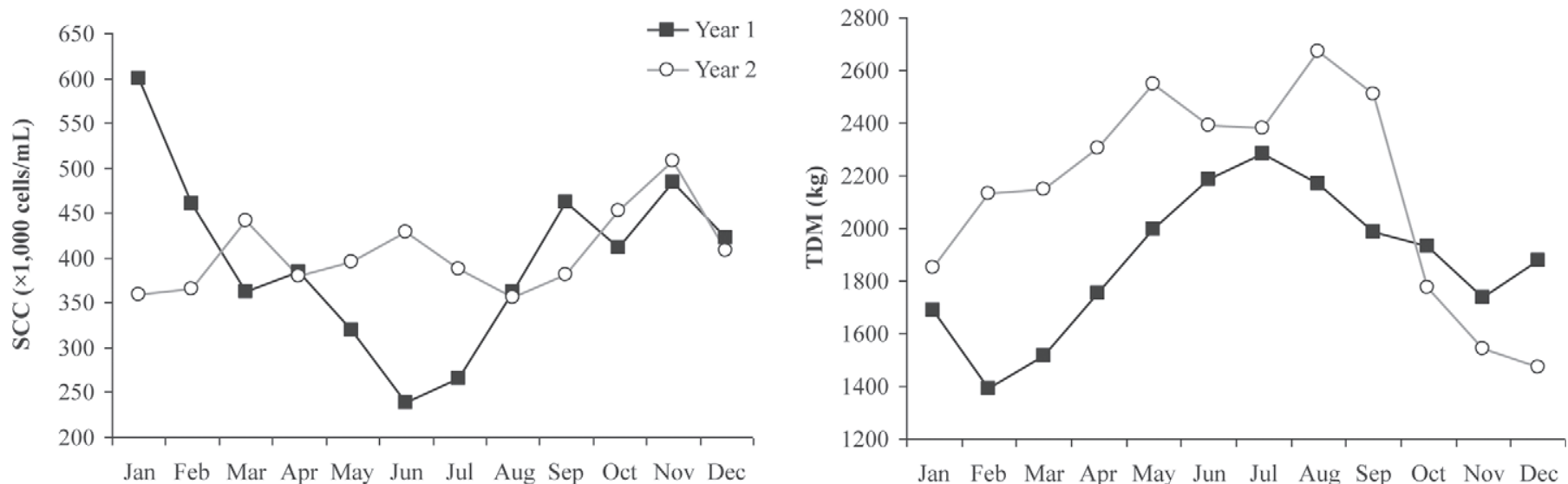

Jan Feb Mar Apr May Jun Jul Aug Sep Oct Nov Dec
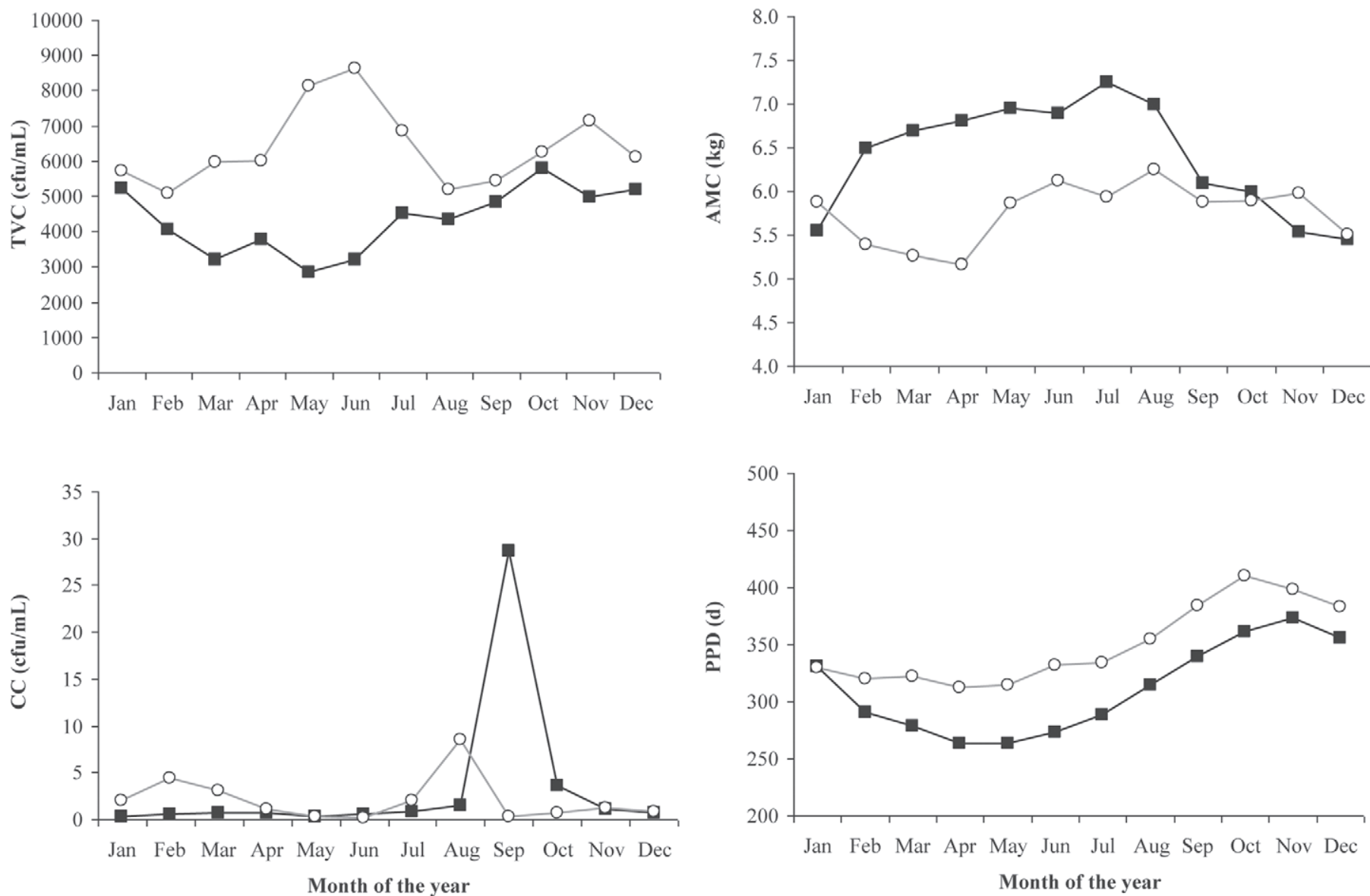

Figure 3. Monthly variation in mean SCC, total viable count (TVC), coliform count (CC), total daily milk (TDM), average milk per camel (AMC), and postpartum days (PPD) according to the year of monitoring. Year $1=$ January 21, 2008, to January 20, 2009; year $2=$ January 21, 2009, to January 20, 2010.

results were confirmed by comparing mean values of TDM, AMC, NMC, and PPD according to SCC categories (Table 1).

Log TVC values increased with increasing NMC (r $=0.32, P<0.001)$ and TDM $(\mathrm{r}=0.16, P<0.001)$, but were negatively correlated to AMC $(\mathrm{r}=-0.40$,
$P<0.001$, Table 2). Similar to SCC, a high positive correlation was found between log TVC and PPD ( $\mathrm{r}=$ $0.45, P<0.001$, Figure 8).

The mixed model revealed that the main sources of $\log$ SCC variation were the following: PPD, TDM, PPD $\times$ season interaction, and season. On the other hand, 
Table 2. Pearson correlation coefficients (r) between milk quality indicators, production parameters, and stage of lactation

\begin{tabular}{lccccccc}
\hline Parameter $^{1}$ & $\log$ SCC & $\log$ TVC & CC & TDM & AMC & NMC & PPD \\
\hline $\log$ SCC & 1 & $0.320^{*}$ & 0.004 & $-0.352^{*}$ & $-0.367^{*}$ & $-0.152^{*}$ & $0.400^{*}$ \\
$\log$ TVC & & 1 & $0.091 \dagger$ & $0.164^{*}$ & $-0.395^{*}$ & $0.320^{*}$ & $0.446^{*}$ \\
CC & & & 1 & 0.032 & 0.024 & 0.015 & 0.021 \\
TDM & & & & 1 & 0.052 & $0.870^{*}$ & -0.063 \\
AMC & & & & & 1 & $-0.441^{*}$ & $-0.550^{*}$ \\
NMC & & & & & & & $0.171^{*}$ \\
PPD & & & & & & & 1
\end{tabular}

${ }^{1} \mathrm{TVC}=$ total viable count; $\mathrm{CC}=$ coliform count; $\mathrm{TDM}=$ total daily milk $(\mathrm{kg}) ; \mathrm{AMC}=$ average milk per camel $(\mathrm{kg}) ; \mathrm{NMC}=$ number of milking camels; $\mathrm{PPD}=$ postpartum days.

$\dagger P<0.05 ;{ }^{*} P<0.001$.

$\mathrm{CC}$, year, and $\mathrm{PPD} \times$ year, $\mathrm{TDM} \times$ year, and $\mathrm{TDM}$ $\times$ season interactions were not significant determinants (Table 4). For log TVC, the significant sources of variation were in the order PPD, TDM, year, season, and $\mathrm{PPD} \times$ season interaction, whereas $\mathrm{CC}, \mathrm{PPD} \times$ year, $\mathrm{TDM} \times$ year, and TDM $\times$ season interactions did not have an effect (Table 4 ).

\section{DISCUSSION}

Despite the growing demand for and interest in camel milk, results on bulk milk quality are scarce in dromedaries (Wernery et al., 2008; Nagy et al., 2013). This paper is the first comprehensive report on long-term monitoring of SCC and microbiological quality in bulk milk in this species. In previous reports, milk quality indicators were determined mainly from samples of individual animals (Wernery et al., 2002; Tuteja et al., 2003; Farah and Younan, 2005; Merin et al., 2005; Eberlein, 2007). As a result, reference values on SCC and TVC in bulk camel milk are not available, and the existing camel milk standard (GSO, 2009) is not supported by relevant scientific data. The aim of this study was to close this gap by providing reliable data for use as reference values on SCC, TVC, and CC in bulk camel milk produced under an intensive management system. In addition, we investigated the relationship between these milk quality indicators and defined factors influencing the long-term variation within the herd.

\section{Comparison of Methods for SCC Enumeration}

In the United States, the PMG staining procedure is considered the standard confirmatory test and the official reference method for DMSCC in goat milk (Paape

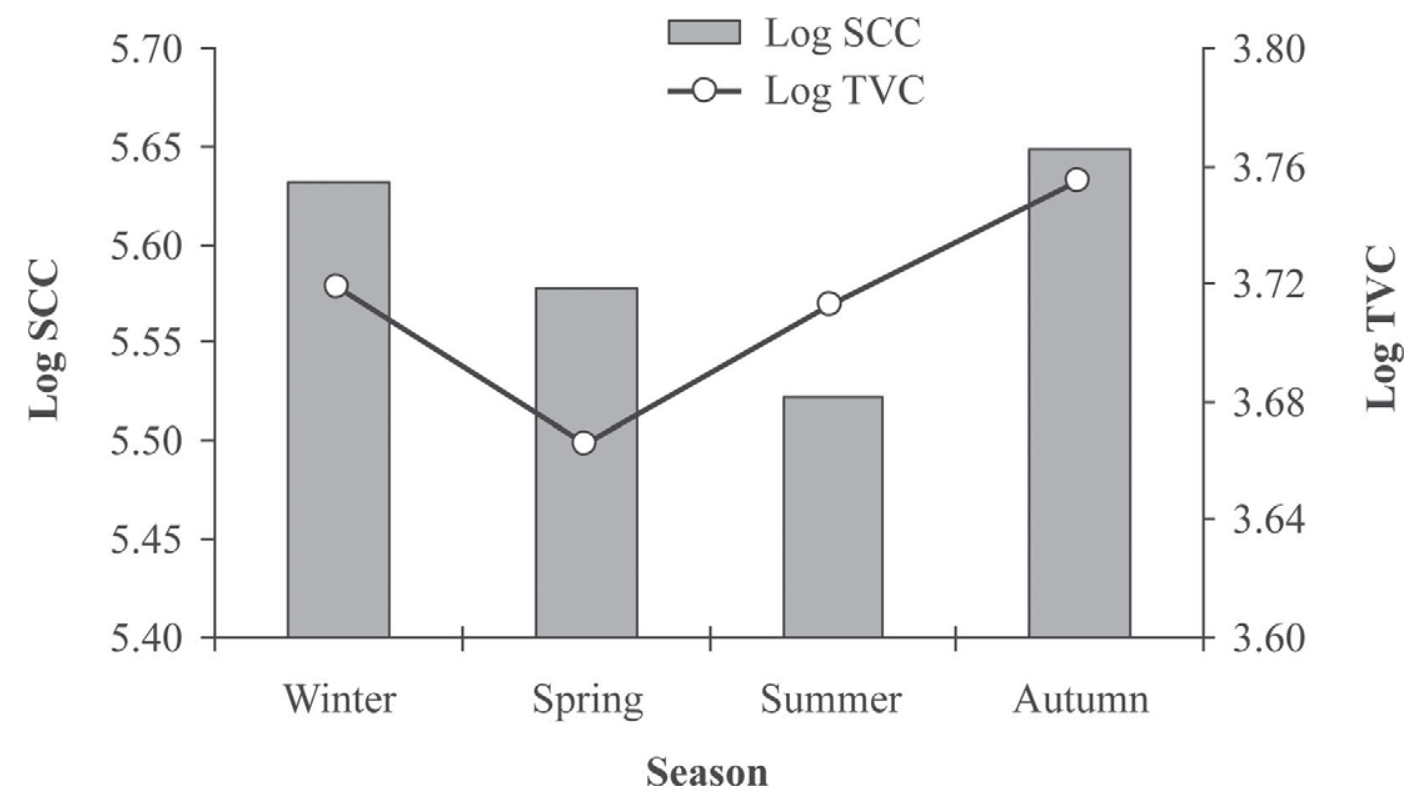

Figure 4. Seasonal changes in mean $\log \mathrm{SCC}$ and $\log$ TVC (total viable count) in bulk camel milk. Season: winter = December to February; spring $=$ March to May; summer $=$ June to August; autumn $=$ September to November. 
Table 3. Production parameters and stage of lactation of dromedaries contributing to bulk milk according to the season of the year

\begin{tabular}{lcccc}
\hline & \multicolumn{4}{c}{ Season } \\
\cline { 2 - 5 } Item $^{1}$ & Winter & Spring & Summer & Autumn \\
\hline TDM (kg) & $1,738^{\mathrm{d}} \pm 317.8$ & $2,042^{\mathrm{b}} \pm 358.1$ & $2,346^{\mathrm{a}} \pm 183.2$ & $1,909^{\mathrm{c}} \pm 342.8$ \\
AMC (kg) & $5.7^{\mathrm{d}} \pm 0.46$ & $6.1^{\mathrm{b}} \pm 0.76$ & $6.6^{\mathrm{a}} \pm 0.53$ & $5.9^{\mathrm{c}} \pm 0.37$ \\
NMC & $308^{\mathrm{d}} \pm 68$ & $343^{\mathrm{b}} \pm 90$ & $361^{\mathrm{a}} \pm 49$ & $324^{\mathrm{c}} \pm 57$ \\
PPD & $334.7^{\mathrm{b}} \pm 32.2$ & $292.2^{\mathrm{d}} \pm 25.7$ & $315.8^{\mathrm{c}} \pm 29.0$ & $375.9^{\mathrm{a}} \pm 25.0$ \\
\hline
\end{tabular}

${ }^{\mathrm{a}-\mathrm{d}}$ Different superscripts within row indicate difference at $P<0.001$ for TDM, AMC, and PPD, and difference at $P<0.05$ for NMC.

${ }^{1} \mathrm{TDM}=$ total daily milk; $\mathrm{AMC}=$ average milk per camel; $\mathrm{NMC}=$ number of milking camels; PPD = postpartum days.

et al., 2001). We successfully adapted the same staining for the enumeration of SCC in camel milk (Nagy et al., 2013). Although comparative studies between DNA-specific and nonspecific stains for DMSCC have not been carried out in camel milk, results of previous studies indicate that values obtained when using methylene blue or Giemsa stains are higher compared with those obtained using the PMG method (Tuteja et al., 2003; Eberlein, 2007). The DMSCC in our study showed good overall repeatability as the mean coefficient of variation of the duplicates was below $3.5 \%$, irrespective of the level of SCC in the milk. However, the direct microscopic method is labor intensive and time consuming and it requires experienced technicians. For this reason, we compared the DMSCC as a reference method with a portable, battery-operated device that uses propidium iodide stain in a cassette (DCC SCC). The device has been used successfully to measure SCC accurately in cow, sheep, and goat milk (Gonzalo et al., 2006b; Berry and Broughan, 2007). Good overall correlation was found between the 2 methods but SCC values were lower with DCC than with the DMSCC method. In addition, values with DCC showed higher day-to-day variation. Gonzalo et al. (2006b) had similar findings in ovine milk. The differences in results between the methods could be explained by the fact that the analytical conditions of DCC were not optimized. It has been shown that, in small ruminants, dilution of samples with a DNA stain, increasing the soak time in cassette, and decreasing the sample storage time improve the overall accuracy of the DCC device (Gonzalo et al., 2006b, 2008; Sanchez-Macias

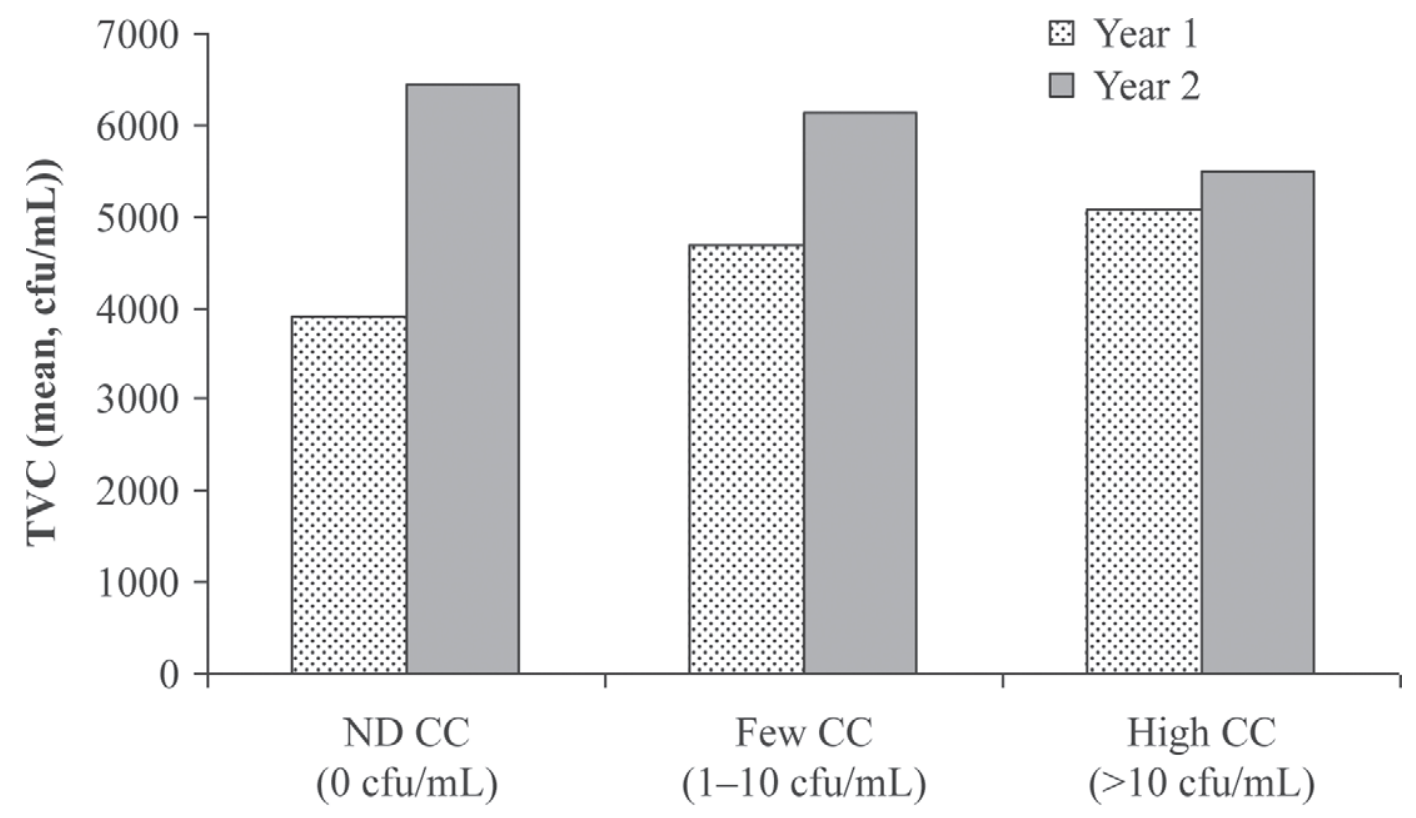

Coliform category

Figure 5. Geometric mean of total viable count (TVC, cfu/mL) of bulk camel milk according to coliform (CC) categories and years of the study. $\mathrm{ND}=$ nondetectable. 


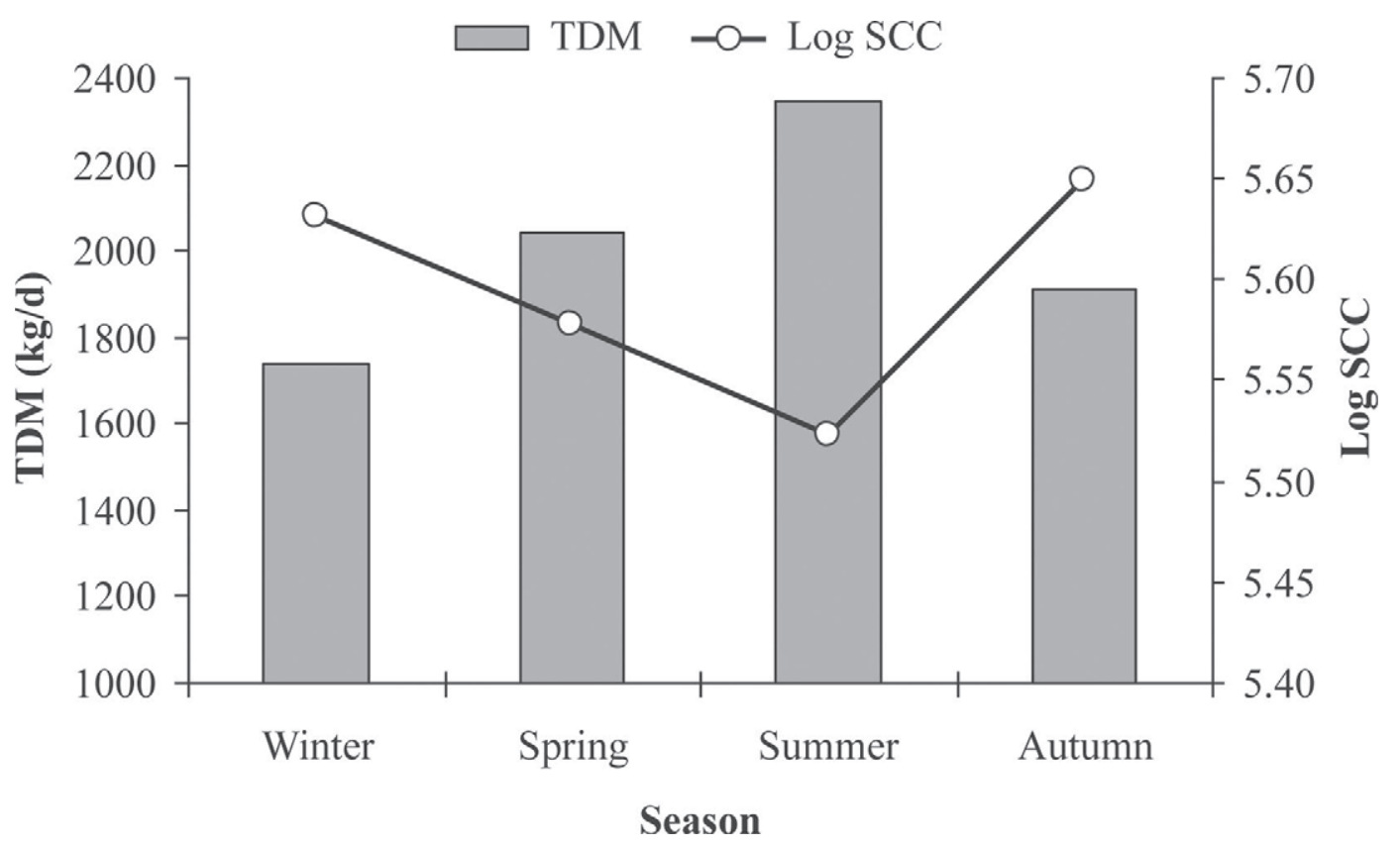

Figure 6. Seasonal changes and negative correlation between total daily milk production (TDM, kg) and log SCC in bulk camel milk (r $=-0.35, P<0.001)$. Season: winter $=$ December to February; spring $=$ March to May; summer $=$ June to August; autumn $=$ September to November.

et al., 2010). Further studies are required to test the effect of analytical conditions (e.g., preservative, age of sample, analytical temperature, dilution, soak time) in camel milk to improve the accuracy of DCC compared with the reference method. We also observed different correlation of the methods between the 2 study years. For few weeks in yr 2, DMSCC values were higher than those of DCC SCC. We cannot exclude the possibility of laboratory error in DMSCC results that might explain this difference.

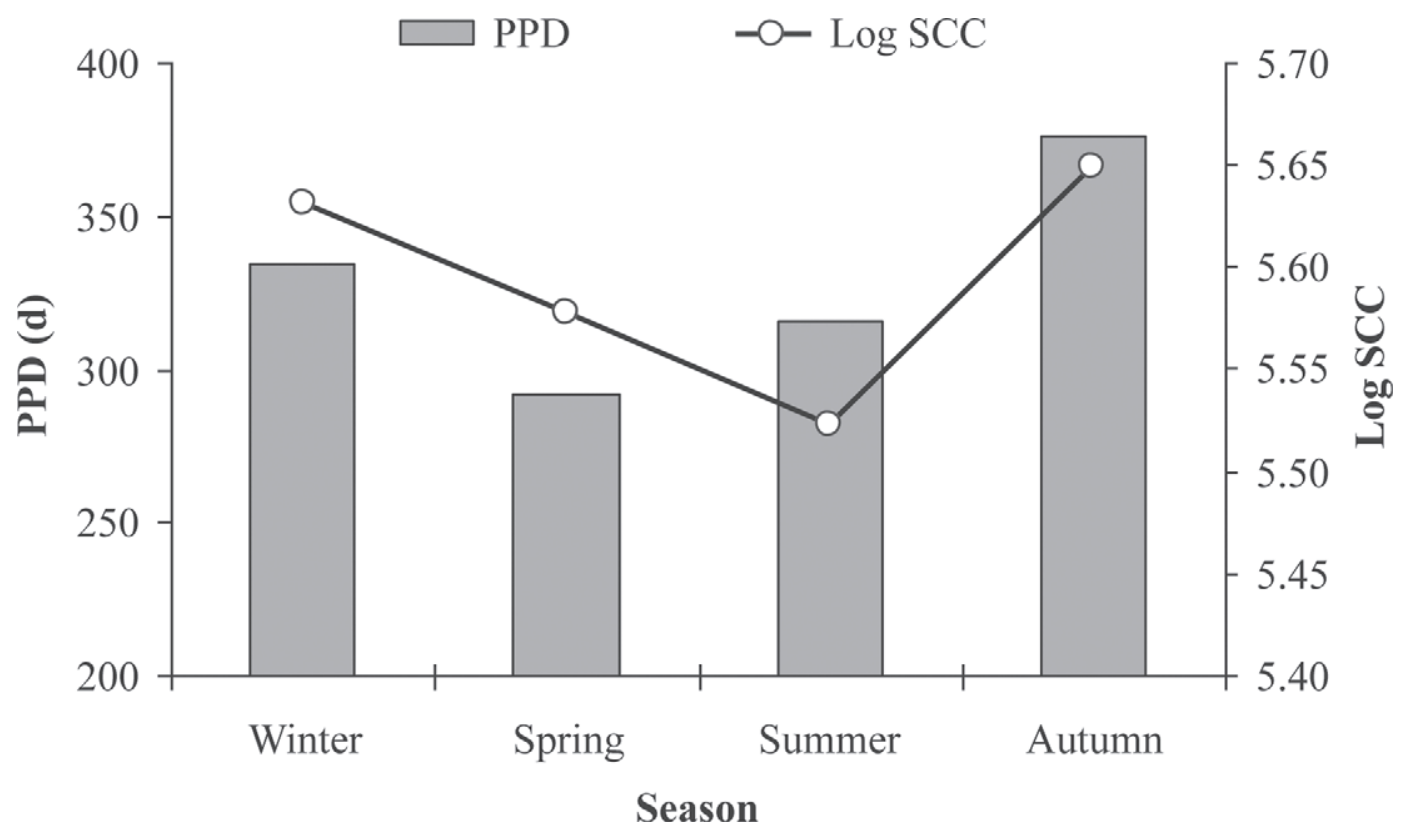

Figure 7. Seasonal changes and positive correlation between the stage of lactation (postpartum days, PPD) and log SCC in bulk camel milk $(\mathrm{r}=0.40, P<0.001)$. Season: winter $=$ December to February; spring $=$ March to May; summer $=$ June to August; autumn $=$ September to November. 


\section{Descriptive Statistics and Seasonal Changes}

The geometric mean of bulk tank SCC over the 2-yr period was close to $400 \times 10^{3}$ cells $/ \mathrm{mL}$, with large variation throughout the study. Counts by the DMSCC method peaked at 927,423 cells $/ \mathrm{mL}$ and values exceeded $500 \times 10^{3}$ cells $/ \mathrm{mL}$ on $14.6 \%$ of the test days. Our finding suggests that SCC values in bulk milk of clinically healthy dromedaries are higher than those from dairy cows but lower than those in sheep and goats. Recent studies from the United States and Europe show that the mean of bulk tank SCC ranges from 187 to $363 \times$ $10^{3}$ cells $/ \mathrm{mL}$ in dairy cows (van Schaik et al., 2002; Jayarao et al., 2004; Berry et al., 2006; Olde Riekerink et al., 2007). On the other hand, mean bulk tank SCC in small ruminants is $>800 \times 10^{3}$ cells $/ \mathrm{mL}$ and values frequently exceed $1,000 \times 10^{3}$ cells $/ \mathrm{mL}$ (Droke et al., 1993; Gonzalo et al., 2005, 2010). Wernery et al. (2008) suggested that raw camel milk could easily comply with the existing European Union regulation of raw bovine milk $\left(\mathrm{SCC}<400 \times 10^{3}\right.$ cell $\left./ \mathrm{mL}\right)$. However, the present study demonstrated that SCC values in bulk milk of this species could be above the threshold of acceptance for cow milk. For this reason, the determination of a legal limit for SCC in bulk camel milk requires further study.

Our present findings in bulk milk were higher than recent reports on SCC values in individual animals (Hamed et al., 2010; Saleh and Faye, 2011). Hamed et al. (2012) reported an arithmetic mean of $100 \times 10^{3}$
Table 4. Sources of variation for $\log$ SCC and $\log$ TVC (total viable count) included in the linear mixed model with stepwise variable selection (on weekly basis) and probability associated with F-value of Fisher test

\begin{tabular}{lccc}
\hline Source $^{1}$ & df & $F$ & $P>F$ \\
\hline Log SCC & & & \\
PPD & 1 & 55.576 & $<0.0001$ \\
TDM & 1 & 29.733 & $<0.0001$ \\
PPD $\times$ season & 3 & 11.474 & $<0.0001$ \\
Season & 3 & 3.249 & 0.025 \\
TDM $\times$ season & 3 & 1.575 & 0.201 \\
Year & 1 & 1.022 & 0.315 \\
PPD $\times$ year & 1 & 0.701 & 0.405 \\
CC & 1 & 0.689 & 0.409 \\
TDM $\times$ year & 1 & 0.303 & 0.583 \\
Log TVC & & & \\
PPD & 1 & 64.073 & $<0.0001$ \\
TDM & 1 & 12.482 & 0.001 \\
Year & 1 & 8.222 & 0.005 \\
Season & 3 & 5.490 & 0.002 \\
PPD $\times$ season & 3 & 3.469 & 0.019 \\
PPD $\times$ year & 1 & 2.613 & 0.109 \\
TDM $\times$ season & 3 & 1.633 & 0.187 \\
TDM $\times$ year & 1 & 1.417 & 0.237 \\
CC & 1 & 0.008 & 0.930 \\
\hline PPD $=$ postpatym & 3 & \\
\hline
\end{tabular}

${ }^{1} \mathrm{PPD}=$ postpartum days; $\mathrm{TDM}=$ total daily milk $(\mathrm{kg}) ; \mathrm{CC}=$ coliform count $(\mathrm{cfu} / \mathrm{mL})$.

cells/mL for dromedary milk based on result from 36 camels. Merin et al. (2005) stated that "good" camel milk does not exceed the acceptable levels for bovine milk; that is, around $120 \times 10^{3}$ cells $/ \mathrm{mL}$ (Chaffer et al., 2000). These studies suggest that in dromedaries, as in cows and sheep, somatic cells in milk remain low

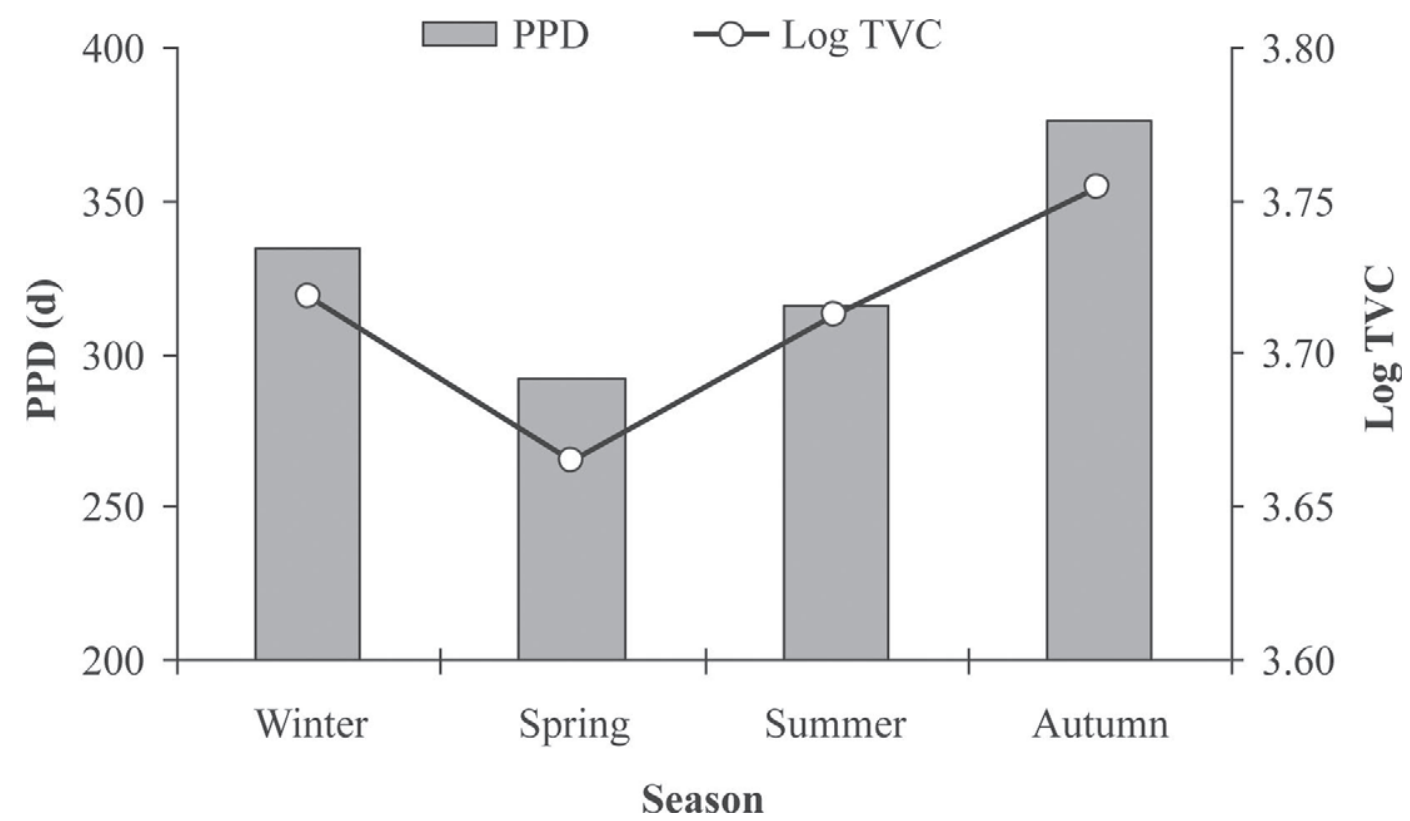

Figure 8. Seasonal changes and positive correlation between the stage of lactation (postpartum days, PPD) and log TVC (total viable count) in bulk camel milk $(\mathrm{r}=0.45, P<0.001)$. Season: winter $=$ December to February; spring = March to May; summer = June to August; autumn $=$ September to November. 
in the absence of IMI. Intramammary infection seems to be the most important factor for increased SCC in this species (Guliye et al., 2002; Saleh and Faye, 2011). These earlier findings also suggest that the level of IMI in our camel population was elevated, resulting in higher bulk milk SCC. However, direct comparison of our results with those from individual samples is questionable for several reasons. In previous studies, samples have been taken from a relatively small number of selected animals kept under different management conditions. Analytical methods were different and other factors that influence SCC levels, such as method of milking, stage of lactation, or season, were not documented or controlled.

In our study, bulk milk SCC showed a distinct seasonal pattern: values decreased from winter to summer and then increased again. However, the seasonal pattern was not pronounced during the second year of the study because of a temporary increase in SCC from May to July. During the autumn to winter period, SCC values were higher. The amplitude of the seasonal change was important because the highest monthly mean (November 2009) was twice as high as the lowest monthly mean (June 2008) during the observation period. We could not correlate this seasonal change in SCC to any previous data in camels. However, such a seasonal pattern has been also demonstrated in both dairy cows and sheep. Berry et al. (2006) reported a highly seasonal change of SCC in Irish dairy herds, with low values from spring to summer and high values during the autumn to winter period. Others also described seasonal change in bulk milk SCC but the variation of the geometric mean was lower $\left(<100 \times 10^{3}\right.$ cell $/$ $\mathrm{mL}$ ) and the peak occurred from July to September (van Schaik et al., 2002; Olde Riekerink et al. 2007; Elmoslemany et al., 2009a). In dairy sheep, month and month within herd were significant variation factors, and maximum SCC values were observed from July to September (Gonzalo et al., 2005, 2010).

In the present study, we demonstrated that good quality camel milk with low TVC (geometric mean: $5,157 \mathrm{cfu} / \mathrm{mL}$ ) can be produced consistently under intensive management. Similar results $($ TVC $<5.0 \times$ $10^{3} \mathrm{cfu} / \mathrm{mL}$ ) have already been achieved on both smalland large-scale farms by applying specific hygienic measures, milking routine, and milk cooling (Wernery et al., 2002; Eberlein, 2007; Nagy et al., 2013). On the other hand, in traditional management systems without proper hygiene and temperature control, the TVC frequently exceeds $100 \times 10^{3} \mathrm{cfu} / \mathrm{mL}$ (Teshager and Bayleyegn, 2001; Khedid et al., 2003; Farah and Younan, 2005; Merin et al., 2005). According to most milk regulations, plate count at $30^{\circ} \mathrm{C}$ for raw cow milk should be $\leq 100 \times 10^{3} \mathrm{cfu} / \mathrm{mL}$. Our present results are well below this legal limit ( $<10 \%$ of the threshold). It is interesting to note that the TVC in our bulk camel milk was in the same range as that reported for good quality bulk cow milk (Jayarao et al., 2004; Elmoslemany et al., 2009a; Bava et al., 2011) but much lower than values published for bulk sheep milk $\left(>120 \times 10^{3}\right.$ cfu/mL; Gonzalo et al., 2006a, 2010).

Changes in bulk milk TVC showed a seasonal pattern that was slightly different from that of SCC - the nadir occurred during the spring, not summer. The mean log TVC was highest during the autumn but the geometric mean remained below $10 \times 10^{3} \mathrm{cfu} / \mathrm{mL}$ even during that period. Such a seasonal change in bacterial count has also been described in bulk cow and sheep milk. However, in cows, the peak tended to occur during the summer and values were lower during winter (van Schaik et al., 2002; Elmoslemany et al., 2009a; Zucali et al., 2011). In sheep, TVC was found to be elevated during the autumn to winter period (Gonzalo et al., 2006a, 2010). According to Pantoja et al. (2009), the seasonal effect varies substantially among farms, being demonstrated at some locations and absent at others. In addition, Elmoslemany et al. (2009a) reported a significant year difference in TVC pattern in cow bulk milk. Our results are in accordance with this finding. The geometric mean of TVC was higher during yr 2 and monthly geometric mean increased from March through July, resulting in a different seasonal pattern compared with yr 1 of the study. Most of the high TVC values $(83 \%)$ in the current study were recorded in the spring and summer of 2009. During this period, disinfectant solution was not available for premilking teat preparation, which explains the elevated mean bulk milk TVC and increased incidence of high values. Following the reintroduction of disinfectant wipes for premilking preparation in July 2009, TVC values decreased immediately. Our rationale is also supported by recent results showing that TVC is associated with animal and paddock hygiene, and premilking teat preparation (Elmoslemany et al., 2009b). Our data suggest that bulk milk TVC is influenced by factors of different origin, and problems of general milking hygiene could obscure the effect of other factors such as season. This was likely the reason why the seasonal pattern of bulk milk TVC differed between the 2 years of the study.

Our CC results coincided with those on bulk milk TVC; CC was $<10 \mathrm{cfu} / \mathrm{mL}$ in $96.5 \%$ of the samples and the mean of the $2-\mathrm{yr}$ period was $2.6 \mathrm{cfu} / \mathrm{mL}$. This result is lower than CC reported in recent studies on bulk bovine milk from various countries (mean CC ranging from 70 to $257 \mathrm{cfu} / \mathrm{mL}$; Jayarao et al., 2004; Pantoja et al., 2009; Zucali et al., 2011). We observed occasional increases randomly throughout the study with a peak $(390 \mathrm{cfu} / \mathrm{mL})$ in September 2008. These higher values 
$(>10 \mathrm{cfu} / \mathrm{mL})$ were associated with well-defined technical problems, mainly with the failure of the automatic washing system. Following the repair of the malfunctions, $\mathrm{CC}$ returned to $<10 \mathrm{cfu} / \mathrm{mL}$. This observation is in agreement with recent findings showing that elevated bulk milk CC is associated with low water temperature, poor equipment hygiene, and milking machine failure (Elmoslemany et al., 2009b; Bava et al., 2011; Pantoja et al., 2011). The overall results of our study on TVC and CC indicate that good hygiene practices (e.g., milking routine, cleaning, and sanitation of equipment) had been developed in the milking parlor and in general, the Hazard Analysis Critical Control Points (HACCP)based food safety management system was efficient.

\section{Correlation Between Milk Quality Indicators}

A high positive correlation was found between bulk milk SCC and TVC, in agreement with results of Gonzalo et al. (2006a) and Pantoja et al. (2009) in sheep and cows, respectively. Others have reported low correlation between SCC and bacterial counts in bulk milk of dairy cows (Jayarao et al., 2004; Elmoslemany et al., 2009a). This positive correlation could be the manifestation of a cause-effect relationship between TVC and SCC, but could also represent parallel changes caused by other factors exerting similar effects on these quality indicators. The association between SCC and subclinical mastitis is well documented. In camels, as in other dairy animals, pathogenic bacteria result in an increase of SCC (Guliye et al., 2002; Saleh and Faye, 2011). However, in our study, TVC exceeded $10 \times 10^{3} \mathrm{cfu} / \mathrm{mL}$ in only $4 \%$ of the cases. In addition, the incidence of clinical mastitis remained low and pathogenic bacteria were rarely isolated from individual samples during the period of the study (J. Juhasz and P. Nagy, personal observation). These observations suggest that IMI did not play a major role in the increase of bulk tank TVC. We assume that the correlation between SCC and TVC was not a simple causal association in our study. Rather, it was the consequence of mutual interaction and the effect of common variation factors.

As expected, no correlation was demonstrated between SCC and CC, in agreement with previous results for cow bulk milk (Jayarao et al., 2004; Elmoslemany et al., 2009a). This finding indicates that the source of coliform contamination and variation factors are different from those of SCC (Bava et al., 2011; Pantoja et al., 2011; Zucali et al., 2011).

The California Mastitis Test has been used as a simple, practical method to diagnose subclinical mastitis in dromedaries (Abdel Gadir Atif et al., 2006; Aljumaah et al., 2011). Based on individual samples, several authors reported strong positive correlation between CMT,
SCC, and bacterial contamination (Abdel Gadir Atif et al., 2006; Eberlein, 2007). Somatic cell counts increased regularly with additional quarter CMT score from 0.37 $\times 10^{3}(\mathrm{CMT} 0)$ to $550 \times 10^{3}$ cells $/ \mathrm{mL}$ (CMT 4; Saleh and Faye, 2011). In agreement with these results, we found a positive correlation between SCC and CMT in bulk camel milk, but mean log SCC was not different between CMT scores 1.5 and 2. In addition, CMT score on most of the test days $(73.6 \%)$ was 2 . Therefore, it seems that the usefulness of CMT for bulk camel milk is limited, as the test did not provide any additional information on the quality of bulk milk.

In this study, a significant but low correlation was reported between TVC and CC including all data. However, a major difference was observed between the years of the study. In yr 1, the positive correlation was confirmed, and mean log TVC was lower when coliforms were not detected. In contrast, during yr 2, a reverse relationship was observed between $\log$ TVC and $\mathrm{CC}$ categories. Notably, our CC categories were rather stringent. For dairy cows, $\mathrm{CC}<10 \mathrm{cfu} / \mathrm{mL}$ is considered good, $\mathrm{CC}<50 \mathrm{cfu} / \mathrm{mL}$ is acceptable, and CC $>160$ $\mathrm{cfu} / \mathrm{mL}$ are categorized as high (Pantoja et al., 2009). Our finding is in agreement with those in dairy cows, demonstrating a low correlation between different bacterial counts (Jayarao et al., 2004; Elmoslemany et al., 2009a). The strength of the relationship indicates that these parameters have different sources. Elmoslemany et al. (2009b) showed that total aerobic count was associated mainly with animal and environment hygiene and premilking teat preparation, whereas CC was related to equipment hygiene, water temperature, and hardness, among other factors. However, some of the risk factors are the same, as CC is also correlated with fecal contamination and teat-end cleanliness. This explains the difference in correlation between the 2 years of our study. During yr 1, most environmental factors were properly controlled and TVC and CC showed parallel changes. During yr 2, however, the effect of independent sources (problem in premilking preparation for TVC and failure of automatic washing for CC) resulted in the disappearance of a positive correlation between TVC and CC.

\section{Changes in Production Parameters and Stage of Lactation, Correlation with Milk Quality Indicators, and Factors of Variation}

All production parameters (TDM, NMC, and AMC) showed the same, pronounced seasonal pattern, with values being highest in summer and lowest in winter. This phenomenon is the consequence of seasonal distribution of births and lactation curve characteristics in this species (Musaad et al., 2013; Nagy et al., 2013). 
Dromedaries are seasonal breeders and most births (70\%) occur from December to March. In addition, the lactation curve peaks during mo 4 or 5 postpartum and persists over $500 \mathrm{~d}$. For these reasons, most newly delivered camels enter production in the spring, and late-lactating animals are usually dried off during the autumn to early winter period. As a result, the number of available milking animals, their individual daily yield, and total daily production are highest during the summer months from June to August. In accordance with this, the stage of lactation of the milking herd also showed a clear seasonal pattern, but its peak and nadir were different from those of the production parameters. We calculated the PPD for each production day, including all dromedaries that contributed to the bulk milk, and this PPD was used as summary data to characterize the stage of lactation of the entire milking herd. Mean PPD was the lowest during the spring (292 d) and highest during the autumn period (376 d). This finding corresponds to the reproductive physiology of the species and to present management practices. The seasonal pattern of PPD indicates that the proportions of early-lactating and late-lactating camels increased during the spring and autumn, respectively.

As expected, production parameters were highly correlated. In addition, AMC and NMC were closely related to the stage of lactation (PPD). For this reason, we chose TDM as a representative production parameter along with PPD as a physiological factor to include in a linear mixed model with stepwise variable selection.

Somatic cell count showed a strong negative correlation with all production parameters and a strong positive association with PPD. Somatic cell count decreased with increasing milk production and decreasing mean postpartum days (spring, summer), and then increased with decreasing production and increasing stage of lactation (autumn, winter). Berry et al. (2006) suggested that the highly seasonal pattern in SCC of bulk cow milk is the function of the seasonal-calving system and changes in SCC throughout lactation. Our findings are in agreement with this and suggest that SCC increases throughout lactation in the milk of dromedaries. Increasing SCC with lactation stage has been documented in cows several years ago (Serieys, 1985). Regarding camel milk, the published results are contradictory. According to Hamed et al. (2010, 2012) and Saleh et al. (2013), SCC in dromedary milk decreases significantly with the stage of lactation. However, those studies included a limited number of camels $(<38)$, individual samples were collected, the method of milking was not documented in 2 studies, and lactation length ( 180 to 300 d) was much shorter compared with that in our study. Hence, these findings on the interaction of SCC and lactation stage might not be valid for machine-milked dromedaries under intensive management with long lactation periods.

Results on correlation between TVC, production parameters, and stage of lactation were more difficult to interpret because of the important year difference in our study. During yr $1, \log$ TVC was negatively correlated with AMC but strongly positively associated with PPD and NMC. In part, this finding is similar to that of SCC interrelationship with production parameters and stage of lactation. We assume that under optimal hygienic conditions, the seasonal pattern in TVC is also the result of seasonal calving and perhaps of the increase in TVC in individual samples throughout lactation. However, this presumption needs to be confirmed by further studies. Nevertheless, if milking hygiene is not controlled properly, the association between these parameters might disappear or change direction. This happened during the second year when TVC increased from April to July due to problems in premilking preparation. As a result, only AMC showed positive and not negative correlations, but PPD and NMC lost interrelation with log TVC.

A linear mixed model with stepwise variable selection was performed on weekly mean data because autocorrelation was detected between daily results up to 4 consecutive days. We observed no autocorrelation between days that were at least $5 \mathrm{~d}$ apart. The model confirmed previous findings on seasonal trends and correlation between milk quality indicators, production parameters, and stage of lactation. For both log SCC and $\log$ TVC, stage of lactation (PPD) and level of production (TDM) were the main factors explaining the variation. In addition, season and $\mathrm{PPD} \times$ season interaction were significant determinants. For log TVC, the effect of year was also confirmed. In general, the models explained most of the variation in $\log \mathrm{SCC}$ and $\log$ TVC. Our results are in agreement with those of Gonzalo et al. (2005, 2006a, 2010) in dairy sheep, indicating that the same external factors influence variation of bulk milk SCC and TVC.

\section{CONCLUSIONS}

This study is the first comprehensive report on the long-term monitoring of SCC and microbiological quality in bulk tank milk of dromedary camels kept under intensive management. We have reported basic reference values for SCC, TVC, and CC in this species that may assist authorities and regulatory bodies in improving existing camel milk regulations. We demonstrated that raw milk of excellent microbiological quality can be produced in dromedaries but SCC levels could exceed the threshold of acceptance set for bovine milk. The use of specific cell counters can be a cost-effective 
alternative to DMSCC in bulk camel milk. We found a strong positive correlation between SCC and TVC. The important variation in both SCC and TVC throughout the year was associated with seasonal changes in production levels (TDM) and stage of lactation (PPD). We suggest that the seasonal variation in milk quality indicators in bulk camel milk is the consequence of seasonal reproduction and lactation curve characteristics of dromedaries.

\section{ACKNOWLEDGMENTS}

The authors express their appreciation and gratitude to the founder and management of Emirates Industries for Camel Milk and Products (EICMP, Dubai, United Arab Emirates) for supporting research and development in lactating dromedary camels. We also thank the entire staff of EICMP for their commitment and devotion in running the farm and carrying out sample collections precisely.

\section{REFERENCES}

Abdel Gadir Atif, E., G. Hildebrandt, J. N. Kleer, B. Molla, M. Kyule, and M. Baumann. 2006. Comparison of California Mastitis Test $(\mathrm{CMT})$, somatic cell counts (SCC) and bacteriological examinations for detection of camel (Camelus dromedarius) mastitis in Ethiopia. Berl. Munch. Tierarztl. Wochenschr. 119:45-49.

Abdurahman, O. A. Sh. 1996. The detection of subclinical mastitis in the Bactrian camel (Camelus bactrianus) by somatic cell count and California Mastitis Test. Vet. Res. Commun. 20:9-14.

Abdurahman, O. A. Sh., H. Agab, B. Abbas, and G. Aström. 1995. Relations between udder infection and somatic cells in camel (Camelus dromedarius) milk. Acta Vet. Scand. 36:423-431.

Abdurahman, O. S., R. Cooray, and S. Bornstein. 1992. The ultrastructure of cells and cell fragments in mammary secretions of Camelus bactrianus. Zentralbl. Veterinarmed. A 39:648-655.

Abeiderrahmane, N. 2005. Modern dairy products from traditional camel herding: An experience in Mauritania. Pages 152-157 in Desertification Combat and Food Safety: The Added Value of Camel Producers. NATO Science Series. B. Faye and P. Esenov, ed. IOS Press, Amsterdam, the Netherlands.

Aljumaah, R. S., F. F. Almutairi, M. Ayadi, M. A. Alshaikh, A. M. Aljumaah, and M. F. Hussein. 2011. Factors influencing the prevalence of subclinical mastitis in lactating dromedary camels in Riyadh Region, Saudi Arabia. Trop. Anim. Health Prod. 43:16051610.

Bava, L., M. Zucali, A. Sandrucci, M. Brasca, L. Vanoni, L. Zanini, and A. Tamburini. 2011. Effect of cleaning procedure and hygienic condition of milking equipment on bacterial count of bulk tank milk. J. Dairy Res. 78:211-219.

Berry, D. P., B. O'Brien, E. J. O'Callaghan, K. O. Sullivan, and W. J. Meaney. 2006. Temporal trends in bulk tank somatic cell count and total bacterial count in Irish dairy herds during the past decade. J. Dairy Sci. 89:4083-4093.

Berry, E., and J. Broughan. 2007. Use of the DeLaval cell counter (DCC) on goats' milk. J. Dairy Res. 74:345-348.

Chaffer, M., G. Leitner, A. Glickmann, C. Van Creveld, M. Winkler, A. Saran, and R. Yagil. 2000. Determination of udder health in camels. J. Camel Pract. Res. 7:171-174.

Droke, E. A., M. J. Paape, and A. L. Di Carlo. 1993. Prevalence of high somatic cell counts in bulk tank goat milk. J. Dairy Sci. 76:1035-1039.
Dufour, S., A. Frechette, H. W. Barkema, A. Mussell, and D. T. Scholl. 2011. Invited review: Effect of udder health management practices on herd somatic cell count. J. Dairy Sci. 94:563-579.

Dulin, A. M., M. J. Paape, W. D. Schultze, and B. T. Weinland. 1983. Effect of parity, stage of lactation, and intramammary infection on concentration of somatic cells and cytoplasmic particles in goat milk. J. Dairy Sci. 66:2426-2433.

Eberlein, V. 2007. Hygienic status of camel milk in Dubai (United Arab Emirates) under two different milking management systems. Doctoral Dissertation. Faculty of Veterinary Medicine, LMU München, München, Germany.

Elmoslemany, A. M., G. P. Keefe, I. R. Dohoo, and R. T. Dingwell. 2009a. Microbiological quality of bulk tank raw milk in Prince Edward Island dairy herds. J. Dairy Sci. 92:4239-4248.

Elmoslemany, A. M., G. P. Keefe, I. R. Dohoo, and B. M. Jayarao. 2009b. Risk factors for bacteriological quality of bulk tank milk in Prince Edward Island dairy herds. Part 2: Bacteria count-specific risk factors. J. Dairy Sci. 92:2644-2652.

Elmoslemany, A. M., G. P. Keefe, I. R. Dohoo, J. J. Wichtel, H. Stryhn, and R. T. Dingwell. 2010. The association between bulk tank milk analysis for raw milk quality and on-farm management practices. Prev. Vet. Med. 95:32-40.

Farah, Z., and M. Younan. 2005. Camel dairy in Eastern Africa: Present state and future perspectives. Pages 173-180 in Desertification Combat and Food Safety: The Added Value of Camel Producers. NATO Science Series. B. Faye and P. Esenov, ed. IOS Press, Amsterdam, the Netherlands.

Faye, B., and G. Konuspayeva. 2012. The sustainability challenge of the dairy sector-The growing importance of the non-cattle milk production worldwide. Int. Dairy J. 24:50-56.

Gonzalo, C., J. A. Carriedo, E. Beneitez, M. T. Juárez, L. F. De La Fuente, and F. San Primitivo. 2006a. Short communication: Bulk tank total bacterial count in dairy sheep: Factors of variation and relationship with somatic cell count. J. Dairy Sci. 89:549-552.

Gonzalo, C., J. A. Carriedo, M. A. Blanco, E. Beneitez, M. T. Juárez, L. F. De La Fuente, and F. S. Primitivo. 2005. Factors of variation influencing bulk tank somatic cell count in dairy sheep. J. Dairy Sci. 88:969-974.

Gonzalo, C., J. A. Carriedo, M. C. García-Jimeno, M. Pérez-Bilbao, and L. F. De La Fuente. 2010. Factors influencing variation of bulk milk antibiotic residue occurrence, somatic cell count, and total bacterial count in dairy sheep flocks. J. Dairy Sci. 93:1587-1595.

Gonzalo, C., B. Linage, J. A. Carriedo, and L. F. De La Fuente. 2008. Short communication: Evaluation of the overall accuracy of the DeLaval cell counter for somatic cell count in ovine milk: Effect of soak time in diluted and undiluted milk samples. J. Dairy Sci. 91:3114-3118.

Gonzalo, C., B. Linage, J. A. Carriedo, L. F. De La Fuente, and F. S. Primitivo. 2006b. Evaluation of the overall accuracy of the DeLaval cell counter for somatic cell counts in ovine milk. J. Dairy Sci. 89:4613-4619.

Gonzalo, C., J. R. Martinez, J. A. Carriedo, and F. San Primitivo. 2003. Fossomatic cell-counting on ewe milk: Comparison with direct microscopy and study of variation factors. J. Dairy Sci. $86: 138-145$.

Goodridge, L., A. R. Hill, and R. W. Lencki. 2004. A review of international standards and the scientific literature on farm milk bulktank sampling protocols. J. Dairy Sci. 87:3099-3104.

GSO [GCC (Gulf Cooperation Council) Standardization Organization]. 2009. GSO 1970/2009: Dairy and dairy products: Pasteurized camel milk. GSO, Riyadh, Saudi Arabia.

Guliye, A. Y., C. Van Creveld, and R. Yagil. 2002. Detection of subclinical mastitis in dromedary camels (Camelus dromedarius) using somatic cell counts and the N-acetyl- $\beta$-D-glucosaminidase test. Trop. Anim. Health Prod. 34:95-104.

Hamed, H., A. Gargouri, Y. Hachana, and A. El-Feki. 2010. Comparison between somatic cell and leucocyte variations throughout lactation in camel (Camelus dromedarius) and cow's milk. Small Rumin. Res. 94:53-57.

Hamed, H., A. J. Trujillo, B. Juan, B. Guamis, A. Elfeki, and A. Gargouri. 2012. Interrelationships between somatic cell counts, lacta- 
tion stage and lactation number and their influence on plasma activity and protein fraction distribution in dromedary (Camelus dromedarius) and cow milks. Small Rumin. Res. 105:300-307.

ISO (International Organization for Standardization). 2003. ISO 4833 Microbiology of food and animal feeding stuffs: Horizontal method for the enumeration of microorganisms - Colony-count technique at $30^{\circ} \mathrm{C}$. ISO, Geneva, Switzerland.

ISO (International Organization for Standardization). 2006. ISO 4832: Microbiology of food and animal feeding stuffs: Horizontal method for the enumeration of coliforms - Colony-count technique. ISO, Geneva, Switzerland.

Jánosi, S., and Z. Baltay. 2004. Correlations among the somatic cell count of individual bulk milk, result of the California Mastitis Test and bacteriological status of the udder in dairy cows. Acta Vet. Hung. 52:173-183.

Jayarao, B. M., S. R. Pillai, A. A. Sawant, D. R. Wolfgang, and N. V. Hegde. 2004. Guidelines for monitoring bulk tank milk somatic cell and bacterial counts. J. Dairy Sci. 87:3561-3573.

Khedid, K., M. Faid, and M. Soulaimani. 2003. Mircobiological characterization of one humped camel milk in Morocco. J. Camel Pract. Res. 10:169-172.

Merin, U., S. Sela, B. Rosen, R. Pinto, and G. Leitner. 2005. Standards for camel milk. Pages 146-151 in Desertification Combat and Food Safety: The Added Value of Camel Producers. NATO Science Series. B. Faye and P. Esenov, ed. IOS Press, Amsterdam, the Netherlands.

Musaad, A., B. Faye, and A. A. Nikhela. 2013. Lactation curves of dairy camels in an intensive system. Trop. Anim. Health Prod. 45:1039-1046. http://dx.doi.org/10.1007/s11250-012-0331-x.

Nagy, P., S. Thomas, O. Marko, and J. Juhasz. 2013. Milk production, raw milk quality and fertility of dromedary camels (Camelus dromedarius) under intensive management. Acta Vet. Hung. 61:71-84. http://dx.doi.org/10.1556/AVet.2012.051.

Norman, H. D., J. E. Lombard, J. R. Wright, C. A. Kopral, J. M. Rodriguez, and R. H. Miller. 2011. Consequence of alternative standards for bulk tank somatic cell count of dairy herds in the United States. J. Dairy Sci. 94:6243-6256.

Olde Riekerink, R. G. M., H. W. Barkema, and H. Stryhn. 2007. The effect of season on somatic cell count and the incidence of clinical mastitis. J. Dairy Sci. 90:1704-1715.

Paape, M. J., B. Poutrel, B. Contreras, J. C. Marco, and A. V. Capuco. 2001. Milk somatic cells and lactation in small ruminants. J. Dairy Sci. 84(E. Suppl.):E237-E244.

Pantoja, J. C., D. J. Reinemann, and P. L. Ruegg. 2009. Associations among milk quality indicators in raw bulk milk. J. Dairy Sci 92:4978-4987.

Pantoja, J. C., D. J. Reinemann, and P. L. Ruegg. 2011. Factors associated with coliform count in unpasteurized bulk milk. J. Dairy Sci. 94:2680-2691.
Petersson, K. H., L. A. Connor, C. S. Petersson-Wolfe, and K. A. Rego. 2011. Evaluation of confirmatory stains used for direct microscopic somatic cell counting of sheep milk. J. Dairy Sci. 94:1908-1912.

Saleh, S. K., G. Al-Ramadhan, and B. Faye. 2013. Monitoring of monthly SCC in the she-camel in relation to milking practice, udder status and microbiological contamination of milk. Emir. J. Food Agric. 25:403-408.

Saleh, S. K., and B. Faye. 2011. Detection of subclinical mastitis in dromedary camels (Camelus dromedarius) using somatic cell counts, California Mastitis Test and udder pathogen. Emir. J. Food Agric. 23:48-58.

Sanchez-Macias, D., N. Castro, I. Moreno-Indias, A. Morales-delaNuez, H. Briggs, J. Capote, and A. Aegüello. 2010. The effect of storage temperature on goat milk somatic cell count using the DeLaval counter. Trop. Anim. Health Prod. 42:1317-1320.

Sargeant, J. M., Y. H. Schukken, and K. E. Leslie. 1998. Ontario bulk milk somatic cell count reduction program: Progress and outlook. J. Dairy Sci. 81:1545-1554.

Serieys, F. 1985. Concentration cellulaire du lait individual de vache: Influence de l'état d'infection mammaire, du numéro, du stade de lactation et de la production laitière. Ann. Rech. Vet. 16:255-261.

Shook, G. E. 1982. Relationship between lactation measures of somatic cell concentration and milk yield. J. Dairy Sci. 65:419-425.

Shumway, R. H., and D. S. Stoffer. 2001. Time Series Analysis and its Applications: With R Examples. 3rd ed. Springer Verlag, New York, NY

Teshager, S., and M. Bayleyegn. 2001. Bacteriological quality of raw milk of camel (Camelus dromedarius) in Afar region (Ethiopia). J. Camel Pract. Res. 8:51-54.

Tuteja, F. C., S. K. Dixit, S. K. Ghorui, A. Deen, and M. S. Sahani. 2003. Prevalence, characterisation and antibiotic sensitivity of intramammary infections in camel. J. Camel Pract. Res. 10:69-77.

van Schaik, G., M. Lotem, and Y. H. Schukken. 2002. Trends in somatic cell counts, bacterial counts, and antibiotic residue violations in New York State during 1999-2000. J. Dairy Sci. 85:782-789.

Wernery, U., St. Fischbach, S. Kletzka, B. Johnson, and S. Jose. 2008 Evaluation of some camel milk parameters used in mammary health. J. Camel Pract. Res. 15:49-53.

Wernery, U., B. Johnson, H. Becker, and E. Maertlbauer. 2002. Microbiological status of raw dromedary milk. J. Camel Pract. Res. 9:1-4.

Zucali, M., L. Bava, A. Tamburini, M. Brasca, L. Vanoni, and A. Sandrucci. 2011. Effects of season, milking routine and cow cleanliness on bacterial and somatic cell counts of bulk tank milk. J. Dairy Res. 78:436-441. 